\title{
Az Internet politikatudományi diskurzusai
}

A szerző röviden összefoglalja, hogy a politikatudomány hogyan próbál megfelelni az Internet gyors elterjedésének tényével. A kérdést elméletileg és az intézményrendszer szempontjából is vizsgálja, mivel a szaktudomány tárgyához az adott esetben nemcsak a témára vonatkozó gondolatok, hanem az érintett intézmények is hozzátartoznak. Kiss Balázs itt közölt tanulmányában csupán arra szorítkozik, hogy a szakirodalom alapján bemutasson néhány olyan, az Internettel kapcsolatban végzett tudományos vizsgálatot, amelyek a politikatudomány terrénumához sorolhatók.

\section{Szerzői információ:}

Kiss Balázs

Politológus, az MTA Politikai Tudományok Intézetének tudományos igazgatóhelyettese és főmunkatársa, az ELTE ÁJK Politikatudományi Intézetének docense. Kutatási területe általában a politikai kommunikáció, s ezen belül különösen az Interneten folyó politikai kommunikáció. A „Politikai kommunikáció az Interneten" címû́ négyéves OTKA kutatási program vezetôje és az „ECampaigning. Governments, Parties, Social Movements" címû nemzetközi workshop szervezôje. Az Internettel kapcsolatos, Boda Zsolt és Berta Kata társszerzőkkel közösen publikált tanulmányai a Politikatudományi Szemlében jelentek meg.

Így hivatkozzon erre a cikkre:

Kiss Balázs. „Az Internet politikatudományi diskurzusai”.

Információs Társadalom IV, 1. szám (2004): 69-96.

https://dx.doi.org/10.22503/inftars.IV.2004.1.5

A folyóiratban közölt müvek

a Creative Commons Nevezd meg! - Ne add el! - Így add tovább! 4.0

Nemzetközi Licenc feltételeinek megfelelően használhatók. 
K i s s B a láz s

Az Internet politikatudományi

diskurzusai ${ }^{1}$

Az alábbiakban arra teszek kísérletet, hogy röviden összefoglaljam, milyen módon kísérelt meg a politikatudomány megküzdeni az Internet létrejöttének és gyors elterjedésének tényével. A kérdésnek legalább két oldala van: egy elméleti és egy intézményes oldala. A tudomány nemcsak leírt, okos gondolatok halmaza, hanem egyúttal intézményrendszer is, s ez így van a szaktudományok esetében is. ${ }^{2}$ Ehelyütt csupán arra szorítkozom, hogy néhány szaktudományos kísérletet mutassak be, olyanokat, amelyek így vagy úgy a politikatudomány terrénumához tartoznak, s ugyanakkor az Internetról is szólnak.

A politikatudományt értelemszerúen akkor kezdi el foglalkoztatni valami, ha annak politikai vonatkozása van. Ám az is természetes, hogy a várható politikai vonatkozásokról elôször nem annyira a szaktudomány, mint inkább általában az értelmiség kezd el töprengeni. A kétféle töprengés - a politikatudósi és az értelmiségi - néha összekeveredik (nemcsak az Internet kérdésében), holott a kettő szétválasztása nem lehetetlen.

Az igazi politikatudományt az különbözteti meg az értelmiségi, a publicisztikai irálytól, hogy nem érzületekből, ötletekből, esetleg politikai szimpátiákból táplálkozik, hanem tudományos paradigmákból. A szaktudomány tehát sokáig nem tehet mást, mint hogy a már hosszabb ideje meglevố, a tudományos közösség által sokszorosan átgondolt és újra meg újra megvitatott saját megközelítéseit, fogalmait és módszereit alkalmazza az új tárgyra is. Az új tárgynak a régi sémákba való belekényszerítése nem megy persze nehézségek nélkül, s egymás után kezdődnek a töprengések a szokásos tudományos eszközök alkalmasságáról, átalakításuk, bővítésük szükségességéről. Ha azután az új tárgy mindegyre kibúvik ezek alól, akkor valaki vagy valakik egyszer csak előállnak egy olyan tudományos arzenállal, ami képessé tesz bennünket leteríteni az új vadat.

Elörebocsátva a végkövetkeztetést, annyit jeleznem kell, hogy ismereteim szerint az Internet eleddig nem állította megoldhatatlan tudományos problémák elé a politikatudomány közösségét: a vázolt szekvenciának azon a pontján vagyunk, ahol megkezdődött ugyan az arzenál felülvizsgálata, de új Internet-paradigma még nem sejlik föl a láthatáron.

\footnotetext{
1 A tanulmány az NKFP támogatásával, az ITTK és az MTA PTI közös kutatásának keretében készült. A kutatás egy részét az OTKA (T34942) is támogatta. Köszönettel tartozom Csigó Péternek, aki értékes tanácsokkal látott el a dolgozat korábbi változatát illetôen.

2 Az intézményes oldallal Pintér Róbert tanulmánya foglalkozik, lásd Pintér 2003.
} 
Éppen ezért a tanulmány a következốképpen tagolódik:

I. Az értelmiségi irodalom jövendölései. Az ide tartozó gondolatmenetek divatja kényszeríti elôször a politikatudományt arra, hogy a tárgykörben megszólaljon.

II. Az empirikus irodalom kutatásai. Kérdéseiket részben az értelmiségi közhelyekbôl, részben a standard politikatudományi paradigmákból veszik. Fő céljuk a közhelyeket ellenőrizni, és a paradigmák alapján áttekinteni, hogy mi a helyzet.

III. A kihívás-irodalom próbálkozásai. A szakirodalomnak ez a része azt az érzést közvetíti, hogy az Internet megjelenése - jobbára más fejlemények mellett - feszegeti a bevett politikatudományi paradigmák korlátait.

\section{I. Értelmiségi jövendölések az Internet politikai következményeiről}

Az új médiumok elterjedése mindig magasra csapó reményeket és sötét félelmeket ébreszt. Így volt ez például a tömegsajtó vagy éppen a távíró megjelenésekor is. A kortársak egy része mérhetetlenül lelkes volt, mert azt várta, hogy az új médium majd közelebb hozza egymáshoz az iparosítás által egymástól elszakított embereket. Azt remélték, hogy lesznek új közösségek, miután a nagyipar felnövekedése nyomán az úgynevezett eredeti közösségek felbomlottak, s az emberek magányos atomokként kezdték tengetni életüket, mit sem tudva az ország közös ügyeiről, a politikáról. Voltak azután borúlátók is. A tömegsajtótól rettegve Angliában még annak a követeléséig is elmentek, hogy az állam vonja vissza azt a törvényt, amelyik kötelezôvé teszi az írni-olvasni tudást, mert ha mindenki tud olvasni, akkor a tömeg olyan óriási keresletet fog támasztani a kultúra piacán, hogy az lerombolja a kultúrát, értsd: aláássa a múvelt kevesek kulturális hegemóniáját (Vincent, 1989). De a politikát is sokan féltették, mert az új és nagy hatású médiumokkal szemben a közönség, a felkészületlen tömeg védtelen, mindent elhisz, amit a médiumok, pontosabban rajtuk keresztül a politikusok el akarnak hitetni vele.

Azt mondhatjuk, hogy az Internet megjelenésének fogadtatása szinte teljes mértékben ezeket a mintákat követte. Az Internet elterjedésének korai szakaszában a fentiekhez hasonlóan derülátó és borúlátó véleményeket, illetve jövendöléseket találunk. Mindkét megközelítés abból indult ki, hogy a számítógép-hálózatok megjelenése radikális változásokat eredményez a társadalomban és ezen belül a kultúrában.

A korai időszak nagy McLuhan-reneszánszot hozott, nem véletlenül. McLuhan népszerúsítette és tovább fejlesztette Harold Innis nézeteit arról, hogy a világtörténelem bizonyos értelemben nem más, mint az uralkodó médiumok közötti váltások története, $s$ a váltások közötti időszakok társadalmi változásait a médiumok technikai potenciáljának kibomlásaként, megvalósulásaként érdemes megpróbálnunk leírni. McLuhan ennek a logikának alapján a televíziótól, de a számítógépek megjelenésétôl is a világ retribalizációját, a világfalu kialakulását várta. Szerinte olyan mértékú változás küszöbén állunk, mint amekkorát az orális kultúrából a grafikusvizuális kultúrába való átmenet okozott, csak most éppen az ellenkezô irányú meta- 
morfózisra lehet számítani. Újra olyan kommunikáció lesz jellemzô, ami az azonnali reakciókon, az egyidejűségen és a világ dolgaiban való részvételen alapul, s ez szükségképpen hatást gyakorol a politikára is.

Manuel Castells részben McLuhan nyomdokain halad tovább, de már a McLuhan-galaxis utáni világról beszél. Az ő felfogásában a hálózatosság, melynek kétségkívül az Internet az egyik, ha nem a par excellence megvalósulása, világleíró metaforává válik. A gazdagság és a gazdaság; de a hatalom, a politikai hatalom meghatározójává is a különböző hálózatokkal, illetve a hálózatok hálózatával fenntartott viszony, a hálózatban elfoglalt hely válik. Nem azok rendelkeznek hatalommal, akik valamilyen bürokratikus szervezetben - legyen az vállalat vagy párt - így-úgy az élre jutottak, hanem azok, akik legalább két hálózat, mondjuk a gazdaság és a politika, vagy éppen a média és a politika hálózatának a metszéspontjait, az úgynevezett „kapcsolókat” (switches) ellenőrzik.

Vannak azután kisebb léptékű változásokat jövendölő gondolatmenetek is. Érdemes óket két csoportba, optimistákra és pesszimistákra osztani, azzal, hogy a megszólaló szerzốk többségénél keverednek egymással a pozitív és a negatív extrapolációk.

A nyolcvanas évek, illetve a kilencvenes évek elejének derülátó gondolatmenetei szerint az Internet okozta átalakulás a modern társadalom egy sor problémájára, köztük a politikai bajokra is gyógyírt hoz.

- Az emberek közelebb kerülhetnek egymáshoz, hiszen a világhálón társakra lelhetnek akár a világ másik sarkában is. Segítséget találhatnak különféle problémáik megoldásához, a legkisebbektôl az életbevágókig. ${ }^{3}$

- Szinte korlátlan információforrás kerül a kezük ügyébe, megvalósulhat végre a demokráciához olyannyira szükséges tájékozott állampolgár eszménye. S ha eddig az ismerethiány jelentősen hozzájárult a politikai passzivitáshoz, most ez a tényezô eltûnik.

- Az állampolgárok nemcsak tájékozottabbak lesznek, hanem aktívabbak is, mindenekelőtt abban a tekintetben, hogy hálóközösségeikben megvitathatják az aktuális politikai kérdéseket és közös véleményt alakíthatnak ki ezekkel kapcsolatban.

- Az elektronikus agorán kialakuló konszenzus pedig online és offline politikai cselekvésre sarkall, a politikusok elektronikus levelek útján történő megszólításától kezdve azok tiltakozó e-mailekkel való elárasztásáig, a különféle témákkal foglalkozó hálózati közösségekben való együttlét IRL módon (in real life) megvalósítható folytatásától az utcai demonstrációk internetes szervezéséig.

- A tömegsajtó, majd a rádió, de leginkább a televízió közvetítette kommunikáció nyomasztó egyoldalúságát felváltja az interaktivitás. Az állampolgár kapcsolatba léphet képviselôjével, politikai pártjának akár a vezetôjével is, és megfordítva, a politikusok a média megkerülésével, tehát torzítás nélkül mondhatják el gondolataikat a választóiknak.

3 Rheingold könyve (Rheingold 1993) számos ilyen legendába illố esettel szolgál. Valószínúleg nem utolsó sorban ezek a jó értelemben vett legendák tették a könyvet olyan fontossá az Internetről szóló diskurzusban. 
- Az emberek az Internet segítségével közvetlenül hallathatják szavukat a közügyekben. Immár jószerivel megoldott vagy rövid idốn belül megoldható technikai kérdés az önkormányzati ülések szinkron követése otthonról, megfejelve a közvetlen beleszólás lehetőségével, hasonlóan a döntéshozatalkor lehetôvé váló elektronikus szavazáshoz.

- Nem lehet immár eltitkolni az állampolgárok elól semmit, hiszen az Internet hatalmas információs tárházában mindent megtalálhatnak, ami érdekli óket. Az Internet alternatív forrás: egyrészt az intézményes hatalommal, másrészt a kétes autonómiájú tömegkommunikációs intézményekkel szemben is. Bárki felrakhatja értesüléseit a hálózatra, illetve megfordítva, az intézményeknek igen hamar elő is lehet írni, hogy minél több dokumentumukat tegyék elérhetôvé az állampolgárok számára.

- Szorosabb, szervesebb kapcsolat fog tehát kialakulni az állampolgárok között, illetve az állampolgárok és a nekik felelős politikai intézmények között. Véget ér az az aggasztó tendencia, melynek jegyében az állampolgárok egyre többet vártak el a politikai intézményektól, miközben egyre kevésbé bíztak meg bennük.

A félelmek is hasonlók a száz vagy ötven évvel ezelốttiekhez:

- Vajon maradéktalanul örüljünk-e annak, hogy az emberek közvetlenül beleszólnak a közügyekbe, hiszen kérdéses, hogy megvan-e ehhez a megfelelő felkészültségük?

- Hová lesz akkor a képviselet elve, melynek jegyében kompromisszumokat is lehetséges kötni, hiszen senkinek az érdekei és vágyai sem érvényesülhetnek tökéletesen?

- A demokrácia nem puszta szavazás, hanem az ügyek és az alternatívák alapos megvitatását is jelenti, melynek során újabb és újabb lehetôségek merülnek fel. Következésképpen, miközben az elektronikus szavazás valóban lehetségessé válik, vajon nem kap-e léket a politikai innováció, a deliberáció nagy hozadéka?

- Az Internet túl sok információval árasztja el az állampolgárokat, olyan sokkal, hogy azok között vagy lehetetlen az eligazodás, vagy az erre irányuló kényszer visszahozza, illetve megerősíti a tekintéllyel bíró intézmények uralmát.

- Az Internet lehetôvé teszi, hogy az emberek olyan módon alakítsanak ki a maguk számára információs környezetet, hogy abból kiszoruljon mindaz az értesülés, ami kellemetlen, de fontos, esetleg életbevágóan fontos volna a számukra. Hiszen lehet, hogy az emberek nem szeretnek például a szegénységrôl hallani, de ha nem hallanak róla, akkor nem is hajlandók tenni az ilyen társadalmi bajok enyhítéséért.

- Az egyéni információs környezet visszalépés a nemzeti televíziózás korszakához képest, mert újra olyan helyzet állhat elô, amelyben az állampolgár csak a saját pártjának az üzeneteivel ismerkedik meg, nem szembesül például legalább a televíziós kampánymúsorok kapcsán - azzal, hogy léteznek más álláspontok is, amelyek nagyon is relevánsak lehetnek számára is.

- Az Internet lehetôvé teszi a totális megfigyelést, lerombolja a magánszférát. Bárki, akár az állam, akár a gazdaság valamely nagyhatalmú szereplője, 
összekapcsolhatja az egyénnel kapcsolatos adatbázisokat, profilt alakíthat ki, ami még akkor is veszélyes, ha nem téves, hát még akkor, ha a hibás profil alapján a vétlen állampolgárt hitelképtelennek vagy éppenséggel bűnözőnek tekintik.

Mindezek az optimista és pesszimista vélekedések mind a mai napig elő-elő kerülnek a szakirodalomban, ugyanakkor mintha kitapintható volna három tendencia. $\mathrm{Az}$ egyiket úgy írhatnánk le mint a technikai determinizmustól a társadalmi meghatározottság felé mutató elmozdulást; a másodikat mint az egységes jövôképek fragmentálódását; a harmadikat pedig mint az Internet unikalitásával kapcsolatos meggyőződés háttérbe szorulását.

Az elsố tendencia alatt azt értjük, hogy míg húsz évvel ezelốtt a megfigyelôk az eljövendő világot az új médium által meghatározott és az új médium sajátosságainak vakon engedelmeskedő világként voltak hajlamosak elképzelni, addig manapság szinte közhely azt tenni meg kiindulópontnak, hogy a meghatározó társadalmi tényezők felülírják a technikát.

A technikai determinizmust naiv vagy téves felfogásként elhelyezni a gondolkodástörténetben nem volna sem méltányos, sem pontos, és nemcsak azért, mert máig élő irányzatról van szó. Az ilyen irányultságú szerzốk nem kis hatást gyakoroltak és gyakorolnak arra, ahogyan a szélesebb közönség - beleértve az üzleti élet és a politika, sốt a kultúra képviselőit is - elképzeli az internetes világot, s ekképpen a technikai determinizmus kitermelte ötletek akár valóságos kísérletekké is váltak és válnak. Ugyanakkor az a közeg, amelyben ezek a kísérletek megvalósulnak, valóban hajlamos arra, hogy a médium lehetőségeiből csak azt engedje megvalósulni, ami az érdekeivel egybevág, továbbá hajlamos a médium fejlesztését is olyan irányba vezetni, hogy a létrejövő megoldások, tartalmak és software-ek - immár a technikai determinizmus erejénél fogva is - meghatározott gazdasági, politikai, kulturális és egyéb érdekeket szolgáljanak.

Azt mondhatjuk tehát, hogy elválik egymástól az, amit a mindenkori új médium - ma az Internet - technikailag lehetôvé tesz, és az, hogy a társadalmi és egyéb körülmények - az adott helyen és az adott időpontban - ennek milyen felhasználását teszik lehetôvé, milyen felhasználására ösztönöznek vagy esetleg kényszerítenek. Ez az álláspont valaha az információs társadalom kutatásával foglalkozó egyik iskolának, a politikai gazdaságtani irányzatnak a tétele volt, utóbb azonban - elsősorban az úgynevezett „megerősítési tézis” (reinforcement thesis) ${ }^{4}$ formájában - többé-kevésbé általánosan elfogadottá vált. Ez a tézis általánosságban mondja ki azt, hogy a mindenkori médiumok alapvetően a fennálló hatalmi berendezkedés megerősítésének érdekében kerülnek használatba. Lehetséges azonban egy demokratikusabb értelmezés is. Ez a kibertér társadalmi beágyazottságát feladatként és nem könyörtelen tendenciaként mutatja be. Stolterman szerint a technika nem valamilyen kész szerszám a közösség létrehozásához, hanem ellenkezőleg, ezt a szerszámot magát is a közösségnek kell kiformálnia (Community Informatics, 2001:43-529). 
A második tendencia a feltöredezés. Ez alatt egyszerúen azt értjük, hogy míg a múltban McLuhannál, Castells-nél és másoknál a világ az új médium fényében, illetve árnyékában egységes logikával megközelíthetőnek mutatkozott, addig manapság inkább olyan vizsgálatokat és gondolatmeneteket találunk, amelyek beérik egyegy aspektus szemrevételezésével, és nem tételezik fel, hogy a médium vagy a hálózat metaforájával tetszés szerint bármelyik világszelet megközelíthető. A világ ebben a tekintetben is újra inkább posztmodern, mint modern arcát fordítja felénk.

Ez a bizonyos fragmentálódás természetes velejárója annak a tendenciának, hogy a normatív és empirikus vizsgálódások körforgása jobbára a normatív irány túlsúlyával indul, majd az empirikus kutatás kerekedik felül. Most éppen mintha az utóbbi szakaszban lennénk: összességében azt mondhatjuk, hogy az Internettel kapcsolatos politikatudományi kutatásokban kezdettől meglevő kettôsségen belül (Groper, 1996) a normatív munkákról az empirikus megközelítésre tevődött át a hangsúly.

Végül, a harmadik tendencia az elôzố kettôboól következik. A remények, illetve félelmek elenyészése nyomán egyre inkább megszúnóben van az a vélemény, hogy az Internet egyedülállóan különleges médium volna, s a hálózatok hálózata is egyre inkább megközelíthetônek látszik más médiumok analógiájára.

Margolis és Resnick (Margolis - Resnick, 1999) arról beszél, hogy amíg meg nem született a Web, vagyis a felhasználóbarátnak mondott grafikus felület, tehát amíg az internetezés elsôsorban szövegalapú, társalgásközpontú kommunikáció volt, addig messzemenôen hinni lehetett abban, hogy az elsố és egyedüli interaktív tömegmédium lesz, amely felszabadítja az embereket az alól, hogy passzív információfogyasztóvá, vagyis olyanná váljanak, amilyenné a bevett elektronikus médiumok teszik ôket. A Web és a hálózati böngészố programok megszületése azonban visszairányította a dolgokat a maguk rendes kerékvágásába ${ }^{5}$, az Internet tömeges felhasználása nem sokban különbözik a televíziózástól, csak éppen itt nem a távkapcsolóval, hanem az egérrel kell a csatornák, illetve az oldalak között váltogatnunk. Ez a gondolatmenet nem technikai determinizmus, hiszen az Internet tömegessé változtatása eminens gazdasági érdek volt és maradt, s ennek az érdeknek a nyomán vált logikussá a minél inkább felhasználóbarát, vagyis minél szórakoztatóbb felületek kifejlesztése.

\section{Az Internetről szóló empirikus irodalom}

Mint említettük, az alábbi áttekintés célja nem az Internet és a politika viszonyának, hanem az erre vonatkozó empirikus kutatások paradigmatikus darabjainak a bemutatása.

Az angolszász tudományos diskurzusban az egyik legkellemetlenebbül csengó minősítés az, ha valamely tanulmányt anekdotikusnak tekintenek. Azokat a vizsgálatokat nevezik így, amelyek a nagy összefüggéseket csupán néhány példára alapozva próbálják meghatározni, tehát módszertanilag nem eléggé védhetők, mert kicsi a minta, végiggondolatlan a paraméterek listája és tisztázatlanok a kategóriák, vagyis túlságosan nagy szerepet játszik a kutató értékítélete és szubjektivitása. Azt a szak-

\footnotetext{
Nem véletlen, hogy a szerzôpár sokat idézett könyvének éppen ez a címe: Politics as Usual.
} 
tudomány is tudja, hogy az új tárgyak vizsgálatakor a kezdetekre szükségképpen az anekdotikus és impresszionisztikus elemzések, fejtegetések jellemzők, elóbb-utóbb azonban színre kell lépnie a szolid tudománynak.

Ha azokat a fóbb témákat szeretnénk látni, amelyek mentén a szakirodalom vizsgálódik, elegendő bármelyik összefoglaló munkát kézbe venni, a fejezetcímek szinte ugyanazok: a technikai lehetôségek, a politikai intézmények jelenléte az Interneten, a hálózatokon folytatott választási kampányok, az állampolgárok internetes politikai társalgása, politikai részvétel a világhálón keresztül (Davis, 1999; Bentivegna, 1999; Wilhelm, 2000; Bentivegna, 2002). Egy-két helyen szerepel az újságírás és a tömegkommunikáció online megjelenése is (Rash, 1997; Selnow, 1998). Amikor pedig akár az Internetet áttekintő tanulmányköteteket, akár különféle konferenciák evvel foglalkozó szekcióinak a programját nézzük, ugyanezekkel a kérdéskörökkel találkozunk. ${ }^{6} \mathrm{~A}$ technikai lehetôségekrôl már szóltunk, ezért lássuk inkább a többi témát. Kérdésünk: milyen megközelítéseket alkalmaztak az empirikus vizsgálódások az utóbbi néhány évben?

\section{Pártok a világhálón}

A politikai szereplők közül a pártok és a politikusok meglehetősen korán ébredtek. ${ }^{7}$ A verseny idejekorán rákényszerítette ôket arra, hogy minél inkább kihasználják az Internet meglétében rejlő lehetőségeket. Viszonylag gyorsan jelentek meg minden országban a helyi politikusok és a politikai pártok internetes lapjai. Nem csoda, hogy a politikatudományi vizsgálódások is hamarosan hozzáfogtak ezeknek az elemzéséhez. Azt akarták kideríteni, hogy az internetes jelenléttel mi is a politikai szereplők célja, s mennyiben használják ki a világháló felkínálta lehetőségeket.

Rosanna De Rosa (De Rosa é.n.) szerint az ilyen irányú empirikus vizsgálatokat három csoportba oszthatjuk:

- A szerkezeti vizsgálódások a honlapok szerkezeti, sokszor technikai leírására korlátozódnak, s azt veszik számba, hogy milyen technikai megoldásokkal találkozik az internetező, milyen gyors a letöltődés, mennyire interaktív a site, milyen a színvilág, a lapstruktúra stb..

- A retorikai elemzés a hálón olvasható szövegeket elemzi, s azok retorikai jellemzőit veti össze például a nyomtatott sajtóéval. A vizsgálat tárgyát itt a stílus, a forma, a képek, a jelentések, a célközönség megszólításának mikéntje és a tárgyalt témák képezik.

-Végül a szocio-kulturális elemzések azt mérik fel, milyen összefüggés áll fenn az online és az offline világ között. Itt szó lehet akár valamely párt online és offline kampánya közötti viszonyról, akár arról, hogy az Internet politikai célokra való felhasználása hogyan függ össze az adott társadalom különféle szociológiai ${ }^{8}$ és kulturális mutatóival, hagyományaival.

\footnotetext{
${ }^{6}$ Az European Consortium of Political Research (ECPR) nevû tekintélyes nemzetközi politikatudományi szervezet kétévente elektronikus témájú workshopokat rendez. 2001-ben Grenoble-ban az elektronikus demokrácia, 2003-ban Edinburgh-ban a civil társadalom és az Internet viszonya volt egy-egy workshop központi témája.

7 Az elektronikus kormányzással foglalkozó kutatásokról egy következố tanulmányban kívánok összefoglalót adni, ezért itt csak a pártokkal és a politikusokkal kapcsolatos elemzésekre szorítkozom.
} 
De Rosa egy másik szempontból két csoportba osztja az elemzéseket: lap-centrikusokra és felhasználó-centrikusokra. Mint látni fogjuk, a szakma mindeddig igencsak hajlamosnak látszik megfeledkezni a felhasználókról.

A pártok és a politikusok internetes megjelenésének vizsgálata egyelőre foóként a megjelenés leírására és osztályozására, illetve annak kipuhatolására korlátozódik, hogy internetes politikájuk formálásában vajon milyen megfontolások vezérlik a szereplőket. ${ }^{9}$ Ennek megfelelôen a kutatók egy része különbözố paramétereket igyekszik kidolgozni, amelyek alkalmazásával az ilyen portálok leírhatóvá és esetleg nemzetközileg, illetve az idő dimenziójában is összehasonlíthatóvá tehetốk.

A talán legjobban kidolgozott paraméter-együttest Rachel Gibson és Stephen Ward (Gibson - Ward, 2001) kínálja. Írásuk gondolatmenete tisztán mutatja fel azt a megközelítést, amelyet úgy jellemeztem, hogy a politikatudomány a meglevô paradigmái alapján igyekszik befogni empirikusan is az Internetet.

Elôször azt tekintik át, milyen lehetőségeket hordoz az Internet kommunikációs médiumként általában, majd ettől függetlenül azt összegzik, hogy melyek a politikai pártok általában vett céljai, s végül az empirikus vizsgálat teoretikus megalapozása érdekében megkísérlik megállapítani, hogy a pártcélok megvalósulásához hogyan kellene optimálisan kihasználni az Internetet. Az optimális kihasználás optimális honlap-struktúrát feltételez. Az ideális honlapon jelen kell lennie egy sor funkciónak, információnak és szolgáltatásnak. Amennyiben ezt a felszereltséget tesszük meg etalonnak, egyfajta extrakciós módszerrel képesek leszünk értékelni az egyes lapokat, számszerúsítve mindazt, ami ott található.

Érdemes röviden felsorolni, hogy milyen paramétereket használnak, már csak azért is, mert a politikai honlapok összehasonlításában más szerzók esetében is jobbára ugyanezekkel a szempontokkal találkozunk, legfeljebb a csoportosítások térnek el.

Gibson és Ward két csoportba osztja a mérendôket. Az egyikbe a funkciók tartoznak, a másikba a teljesítmény. A funkciók ez esetben azt foglalják össze, hogy a honlapok milyen feladatot kívánnak megoldani az állampolgárokkal való kapcsolattartásban; a teljesítmény pedig azt, hogy ezek a funkciók mennyire hatásosan múködnek. Az Internet kommunikációs eszköz, s ennek jegyében a funkciók az információáramlás iránya alapján csoportosíthatók.

- Vannak felülrôl lefelé irányuló információmozgást lehetôvé tevố portálfunkciók (például pártprogramok, nyilatkozatok, személyi anyagok, eseménynaptárak elérhetősége), amelyek egyszerűen közölnek bizonyos dolgokat a látogatóval.

- Az alulról felfelé mutató irány olyan funkciók meglétében mutatkozik meg, mint például az adományozást lehetôvé tevő szolgáltatás.

- A következő csoport a horizontális kapcsolódásoké. Ide a más pártok, újságok, támogató szervezetek stb. felé mutató linkek tartoznak. ${ }^{10}$

- A negyedik paraméter-együttes az interaktivitást mutatja. Ez is kétféle lehet: aszinkron (például a portálhoz tartozó fórum) és szinkron (például chat-room vagy online társalgás valamely politikussal).

\footnotetext{
8 Ennek legkiválóbb, óriási hatású múvelōje Pippa Norris, akinek a munkái ma már megkerülhetetlenek. A vonatkozó irodalom rövid áttekintését és felsorolását lásd Gibson and Ward (2001).
} 
A teljesítmény mérésére olyan szempontokat alkalmaznak, mint például a képek száma, a különbözô multimédiás eszközök megléte, a frissítés gyakorisága, az elérhetôség gyorsasága, az eligazodás egyszerú vagy éppen nehézkes volta, továbbá az a készség, hogy a honlapra küldött üzenetekre érkezik-e válasz, s ha igen, milyen gyorsan és milyen minőségben.

A kutatók reményei szerint alaposabb és ismételten végrehajtott elemzések nyomán olyan kérdésekre kaphatunk válaszokat, mint például az, hogy a pártok és politikusok idővel, honlapjuk sorozatos megújításai alkalmával milyen irányban fejlesztenek: nagyobb figyelmet fordítanak-e a részvételt ösztönzố strukturális elemekre, vagy inkább az a helyzet, hogy az internetes politikai kommunikáció is belesimul az offline kampányolás mintáiba? A módszer azt ígéri, hogy összehasonlíthatóvá teszi különbözố országok politikai portáljait is, és segítségével felmutatható, hogy egy-egy helyen inkább a részvétel dominál, míg másutt az adománygyújtés, vagy éppen a puszta pártpropaganda. Hasonlóképpen választ remélhetünk olyan típusú kérdésekre is: vajon a jobb és a baloldal különbözô felfogása tetten érhetô-e azon, ahogyan a párt-honlapok fel vannak építve.

Gibson és Ward értelemszerúen a mérhető elemekre helyezi a hangsúlyt, a különféle közlemények szószámára, bizonyos szolgáltatások meglétére és hiányára stb. Módszerük ennélfogva nem képes és nem is akar befogni olyan tényezóket, mint a szimbólumvilág, holott ezek sem érdektelenek. Berta Kata (Berta, 2001) a magyar politikai pártok 2001-es honlapjait vizsgálva érdekesen mutatott rá arra, hogy míg a régebbi jobboldali pártok (FKGP, MDF, MIÉP) honlapján karakterisztikus a zöld szín, addig a Fidesz ezt a színt nem alkalmazza, színválasztása inkább pragmatikus (vidám, meleg színek). A honlapok szimbolikájának felvételét az elemzési szempontok közé Boda Zsolt (Boda, 2003) is elengedhetetlennek tartja.

Gibson és Ward paramétereit nemcsak azért látszott érdemesnek ismertetni, mert a párt-honlapok meglehetősen jól vizsgálhatók általuk. A két szerző egy korábbi munkájában kimond egy tézist, amelyet azóta már többen is teszteltek. Ez az úgynevezett kiegyenlítódési tézis, ami azt feltételezi, hogy az Internet - a maga viszonylagos olcsósága okán, továbbá azért is, mert a nagy pártok portálja ugyanolyan valószínúséggel kerül a látogató útjába, mint a kis pártoké - lehetôvé teszi, hogy a nagy pártok versenyelónye csökkenjen. ${ }^{11}$

A teszteredmények vegyesek. Akár az olasz Bentivegnát (Bentivegna, 2002:1178) ${ }^{12}$, akár a magyar Dányi Endrét (Dányi, 2002:33) olvassuk, vizsgálataikból levont következtetésként azt találjuk, hogy a tézis nem állja meg a helyét: minél hosszabb ideje politizál valamely párt, és minél több pénzból gazdálkodik, annál jobb, mívesebb a honlapja, nem igaz tehát, hogy az újabb vagy a kisebb pártok az Internet segítségével próbálnak elônyre tenni szert. Ugyanakkor Semetko és Krasnoboka (Semetko - Krasnoboka, 2003:91) azt állítja, hogy Oroszország és Ukrajna esetében a tézis igaz, az új pártok az Internetnek köszönhetően képesek felvenni a versenyt a régiekkel.

${ }^{10}$ A linkek elemzésének politikára is alkalmazható érdekes kísérlete található Varga Barbara írásában (Varga 2001).

${ }^{11}$ Lásd: „U.K. political parties and the Internet. 'Politics as Usual' in the new media?” Harvard International Journal of Press/Politics 3: 14-38. 
Maguk Gibsonék úgy találták, hogy a kreativitás tekintetében érvényesül a kiegyenlítôdés. Igaz ugyan, hogy általában éppen a pártok azok a politikai szereplôk, amelyek eddig nemigen törekedtek innovatív megoldásokra, hanem beérték azzal, hogy nem maradnak le a versenytársak mögött, ${ }^{13}$ ám ezen belül igenis van különbség a kis és a nagy pártok között. A kis pártok lapjain inkább érhetố tetten végiggondolt koncepció, és ez nem csoda. Ök azok, akik gyengébb anyagi háttérrel rendelkezve kiszorulnak a hagyományos tömegkommunikációból, s ha időnként mégis bekerülnek egy-egy híradóba, imázsuk - éppen a ritka szereplés miatt - igencsak megsínyli a szerkesztôi tudatlanságot vagy a torzítást.

Az elmondottakhoz még annyit tehetnénk hozzá, amit Norris (Norris, 2003:25) állapít meg: a párt-honlapokról szóló irodalom eddig nem vizsgálta azt, hogy a választók hogyan használják a portálokat. De Rosa kategóriái alapján tehát valóban csak honlapcentrikus elemzéseket találunk, különösen, ha nem érjük be az anekdotikus leírásokkal.

\section{Választási kampány a világhálón}

A politikatudományi vizsgálatok és különösen a politikai kommunikáció-kutatások elsôrendû́ témája a választási kampány. Érthetô, hogy az állampolgárokat, és fốképpen az érdekelteket (a politikusokat, a pártokat és a szervezeteket) elsôsorban az a kérdés érdekli, hogy hogyan lehet nyerni a választásokon. Az alábbiakban mintegy két legyet ütünk egy csapásra, amikor a választási kampányok internetes megjelenése körüli vizsgálódásokat a politikusi honlapok leírására irányuló egyik kísérlettel illusztráljuk.

A politikusok honlapjai a vizsgálódások fontos tárgyai. Semetko és Krasnoboka (Semetko - Krasnoboka, 2003:93) szerint az általuk vizsgált két országban a pártvezérek honlapja népszerúbb, mint a saját pártjuké, és hasonlókat mondhatunk Magyarországon például Dávid Ibolya és az MDF esetében is (Boda, 2003). Az Internet tehát, mint a televízió megszületése óta minden új médium, erősíti azt a tendenciát, amit a politika perszonalizációjának szokás nevezni, vagyis hogy a politikai életben, de fóként a politikai kommunikációban háttérbe szorulnak az intézmények, $s$ a politika a vezérek mint posztmodern gladiátorok küzdelmeként, személyes víziójuk és karizmájuk vetélkedéseként jelenik meg. A perszonalizációhoz azonban nemcsak a vezérek felragyogása tartozik hozzá, hanem az is, hogy minden egyéni politikus szükségét érzi határozott saját arcél, imázs kialakításának. Erre pedig kevés jobb eszközt találhatnak az Internetnél.

A politikusi honlapok elemzésében kövessük Sara Bentivegnát (Bentivegna, 2002:112-120), aki a választási kampány időszakában létezett olasz politikusi honlapokat kategorizálta. Ót négy szempont vezette vizsgálódása során:

1. az adott honlap mennyire informatív,

2. mennyire mobilizál,

3. mennyiben épít közösséget,

4. és milyen szolgáltatásokat nyújt.

${ }^{12}$ Bentivegna hozzáteszi, hogy ezt a felismerést erôsítik az olasz mellett az amerikai, brit és új-zélandi vizsgálatok is.

${ }^{13}$ Bentivegna (2002: 74) ki is mondja, hogy minél centralizáltabb és stabilabb szervezettel rendelkezik egy párt, annál inkább hajlamos arra, hogy ezt a felépítést változatlanul átvigye a világhálóra is. 
Ezek alapján Bentivegna ötféle honlapot különböztet meg. Ezek rendre gazdagabb és gazdagabb tartalmat kínálnak a látogatóknak:

1. A kirakat-honlap (sito vetrina) a legszerényebb, a politikus e-mail címének közlésén túl, ami a közösségépítő tartozékok közé számít, csak a tájékoztatást szolgálja, mégpedig a jelölt életrajzával, fényképeivel, nyilvános megszólalásainak szövegével.

2. A faliújság-honlap ${ }^{14}$ (sito bacheca) a tájékoztatást kiegészíti a fontosnak tartott újsághírekkel; közli a politikus kampányának időtervét is, ezzel és a választók támogatásának kérésével kíván mobilizálni. A honlapon keresztül (az e-mail cím mellett) a látogató - mint egyfajta elektronikus faliújságon - küldhet üzeneteket, s ezzel erôsödik a közösségépítő jelleg; végül kiegészítő szolgáltatásként politikai és intézményi linkek is találhatók a honlapon.

3. A röplap-honlap (sito volantino) az informálás és a mobilizálás tekintetében gazdagabb az elôző kettőnél, ugyanis politikai programismertetốt, illetve választási propagandaanyagot is tartalmaz, erre utal a „röplap” elnevezés.

4. A közösség-honlap (sito community) - mint a neve is mutatja - a közösségépítô funkcióját illetốen erôs, mégpedig annak köszönhetôen, hogy fórumot múködtet, és szondázza a látogatók véleményét különféle kérdésekben. Emellett informatívabb is az előző háromnál, mert összehasonlítja a különféle politikusi programokat; a mobilizáló funkció különféle kampánytárgyak (kitűzốk, trikók stb.) eladásával gazdagodik; végül a linkek listája kiegészül a tömegkommunikációs intézményekével, és a látogató különféle letölthetô anyagokhoz is hozzájuthat.

5. A hi-tech honlap (sito hi-tech) a leggazdagabb mind a négy vonatkozásban: pénzbeli támogatás is nyújtható rajta keresztül; társalgó szoba és hírlevél révén erôsíti a közösségépítést; továbbá elektronikus postaláda, SMS-küldési lehetőség és játékok is szerepelnek a szolgáltatások között.

A vizsgálat lényege az, hogy a kutató felméri a különféle típusokhoz tartozó lapok előfordulási gyakoriságát, az egyes fajtákat korrelációba hozza régi és új pártokkal, régi és új politikusokkal, a jobb és a baloldallal stb... A honlap-tipológia alapján végzett elemzés megerôsíti az úgynevezett normalizációs tézist, miszerint az Internet továbbviszi az offline világban megfigyelhetố viselkedési modelleket, tehát a helyzet mélységesen konzervatív, az Internet felöl semmi sem fenyegeti a politika szokásos menetét (Bentivegna, 2002:117).

\section{A tömegkommunikáció az Interneten}

A politikai szervezetek és a politikusok után a politikai élet talán legfontosabb szereplői a tömegkommunikációs médiumok. Ebben a témában Wayne Rash munkáját (Rash, 1997) ismertetjük, annak ellenére, hogy az kifejezetten az anekdotikus leírások körébe tartozik. Nem találtunk azonban ennél érdekesebb és szakszerúbb írást.

${ }^{14}$ Dányi Endre (2002) is használja a metaforát, de ổ kiterjeszti minden magyar kampány honlapjára. 
Rash a politika és a tömegkommunikáció interakciójáról beszél, vagyis nem arról, hogy a tömegkommunikációs médiumok hogyan jelennek meg az Interneten, milyen módon gyújtenek, vagy éppen adnak tovább politikai híreket. ${ }^{15}$ Rash-t sokkal inkább annak a módja, illetve módjai érdeklik, ahogyan a politikai intézmények az Internet segítségével megkísérlik hírekkel ellátni, sốt akár manipulálni is a tömegkommunikációt.

Témaválasztása annak az időszaknak a pontosan lenyomata, amelyikben a beszámoló íródott. Meglehet - mondja Rash 1996 táján - hogy a hagyományos tömegkommunikációnak befellegzett, mert ezután mindenki a világháló révén fog tájékozódni, ám egyelőre még az offline média az uralkodó információs forrás az állampolgárok számára, s a politika sem tehet mást, mint hogy alkalmazkodik ehhez. Még leginkább azt mondhatjuk - s ez képezi Rash egyik kiindulópontját -, hogy az Internetet éppen az újságírók használják a legsưrúbben tájékozódásra. Ha pedig ez így van, s a politika ehhez a tényhez is alkalmazkodik, akkor talán az a legfontosabb kérdés, hogy milyen módon megy végbe a politika és a tömegkommunikáció együttmúködése az Internet közvetítésével, bármit értsünk is ez alatt. ${ }^{16}$

A szerző nyolcféle módját találta annak, ahogyan a politika és a tömegkommunikáció ilyen értelemben vett interakciója végbe szokott menni:

1. Hírek „elültetése” (planting news). A politikai szereplő szeretne valaminek tömegkommunikációs tálalást szerezni, ezért az adott hírt elhelyezi egy olyan honlapon, amelyikrốl tudja, hogy az újságírók sưrún látogatják. Azután csak vár, amíg valaki megkeresi ốt további részletekért.

2. Reagálás a hírekre (spinning newes). A politikai szereplő a bekövetkező eseményekkel kapcsolatos álláspontjáról e-mailben vagy hírlevélben azonnal tájékoztatja az újságírót. Amennyiben ez szokássá válik, az újságíró valószínúleg megvárja a reagáló e-mailt, mielőtt megírná cikkét az eseményről. Ezáltal a szóbanforgó szereplő nagyon korán képes belépni a hírciklusba, ellenfelei nem uralhatják háborítatlanul az adott esemény konstrukcióját, az újságíró pedig gazdagabban tájékoztathat a fejleményekról.

3. Hírré válás (becoming newes). Az Internet fejlődésének korai időszakában, amikor az új médium a modernség, a korral való lépéstartás nagy szimbóluma volt, a politikai szereplő́k számára az Interneten való jelenlétük puszta ténye sokkal fontosabbnak tünt, mint a honlapjuk tartalma. Akkoriban az internetes megjelenés terén tanúsított ügyesség a vetélytársak közötti mérkőzés egyik aspektusának minősült. És valóban, a tömegkommunikáció rendszeresen foglalkozott az egyes szereplők internetes teljesítményével.

4. Háttér-információ nyújtása (providing newes background). Ez a funkció nem több mint az adott politikai szervezet vagy politikus programjának, beszédeinek, parlamenti felszólalásainak elérhetővé tétele az Interneten. Arra mindig lehet számítani, hogy az újságírónak kevés az ideje, tehát a világháló mint gyorsan elérhető információs forrás, ahol az anyagok ráadásul írott, vagyis kön-

${ }^{15}$ Erről inkább Ladnert érdemes elolvasni.

${ }^{16}$ Egy helyütt (Rash 1997:119) éppenséggel szürreális táncnak nevezi ezt az együttmúködést. 
nyen átemelhető és számítógéppel egyszerűen feldolgozható formában rejtôznek, túlságosan erôs csábítást jelent a számára, aminek nem tud ellenállni. Böngészés közben pedig a keresố hamarosan az adott honlapokra téved.

5. Hírforrások megnevezése (providing newes sources). A politikai szereplő rendszeresen tájékoztatja a médiát arról, hogy egyes ügyekben kihez, melyik pártfunkcionáriushoz érdemes fordulni. Nem kerül minden információ a világhálóra, azok jó része továbbra is csak személyes konzultáció útján szerezhetốk meg, minél specifikusabb területrôll van szó, annál inkább, s ezért szükséges az illetékesek kijelölése.

6. Tájékoztatás az információhoz való hozzáférés mikéntjérôl (providing news access). A politikai szereplő rendszeresen tájékoztatja az újságírókat arról, hogy adott esetben bizonyos kérdésekról hol juthat hozzá a párt, illetve a politikus által hozzáférhetővé tett információhoz. Ez főként hirtelen szükségessé váló tájékozódáskor segítheti a tömegkommunikációt, vagyis olyankor, amikor nincs idô vagy mód közvetlen kapcsolatba lépni az adott szereplôvel, hiszen például egy szóvivő egyszerre csak egy riporternek képes interjút adni, a lapzárta pedig közeleg.

7. Nyomás gyakorlása tömegkommunikációs tálalás érdekében (providing coverage pressure). A politikus vagy a politikai szervezet elhelyez valamilyen anyagot a honlapján, majd híveit arra buzdítja, hogy kérjenek eligazítást a sajtótól az adott ügyben. Az újságírók remélhetốleg nemsokára rátalálnak a publikálni vágyott anyagra. Ez fớként a kis médiavisszhangban részesülő szereplők számára jó megoldás arra az esetre, ha sehogyan sem sikerül észrevétetniük magukat a médiával.

8. Végül a politika és a sajtó hagyományos kapcsolattartása, a sajtóközlemények eljuttatása (distributing press releases) is felgyorsul és biztosabbá válik az Internet segítségével. A közvetlenül az újságíró elektronikus postaládájába érkezô sajtóközlemény nem várakozik hosszan a küldô, majd a címzett postázójában, magán a postán, és nem kallódik el azután a sok papír között. Hozzátehetjük persze, hogy a spam divatja idején, továbbá akkor, amikor mindenki ezt az utat járja, egy-egy ilyen küldemény legalább olyan könnyen elveszhet a sok hasonló között, mint korábban egy-egy levél a többi közt, ám a gyorsaság és a megbízhatóság kétségkívül biztosabb erénye az Internetnek, mint a hagyományos postázásnak.

Láthatjuk, hogy Rash felfogása a hagyományos politikai kommunikáció-felfogásokat követi, vagyis hogy a kezdeményező mindig valamilyen politikai szereplő, a tömegkommunikáció pedig csupán közvetíti az információt. Olyan „interakció” ez, amelyben a tömegkommunikáció igazából csak reagál és sohasem kezdeményez, gyakorlatilag még akkor sem - például hírek „elültetése” esetében - amikor azt hiszi magáról. 


\section{Az állampolgárok társalgása az Interneten}

Az egyik olyan terület, amelytốl a megfigyelők valaha sokat vártak, illetve igencsak féltek, az állampolgárok politikai egymásra találása az Interneten. Ennek legalább két fajtája van: a puszta társalgás, és az olyan eszmecsere, ami további online politikai aktivitásba megy át, s így érintkezik az állampolgárok általában vett internetes politikai részvételének kérdéskörével.

Az internetes társalgások kutatóinak (Bentivegna, 1999 és 2002; Davis, 1999; Kumin, 2001; Hill-Hughes, 1998; Schalken, 2000 [in Democratic Governance]; Schneider, 1997; Wilhelm, 2000) egy része azt vizsgálja, vajon deliberatív jellegúek-e az internetes társalgások. Schneider 46 ezer üzenetet elemez, de a többiek sem érik be ezres mintáknál kevesebbel. Jóllehet Schneider teljesítményének mindenki tisztelettel adózik, ehelyütt inkább Wilhelm vizsgálatait idézzük.

Wilhelm kifejezetten azt a kérdést teszi fel, hogy mennyire deliberatívak az online politikai társalgások, s ennek a megválaszolásához dolgoz ki empirikus módszert, majd azt alkalmazva jut el következtetéseihez.

Az első feladat természetesen annak eldöntése, hogy miben áll a deliberáció, s az ô megközelítése alapján a kritikai-racionális reflexiót kell deliberatívnak tekintenünk. Hogyan lehet ezt mérni? Wilhelm itt Fishkint hívja segítségül, aki szerint három feltétel fennállása esetén beszélhetünk deliberációról:

1. tartalmas politikai üzenetek cseréjérôl van szó;

2. lehetőség van folyamatos vitára, melynek során a résztvevő́k reflektálhatnak az üzenetekre;

3. az üzeneteket interaktív módon dolgozzák fel a résztvevốk, s ennek során az egyes hozzászólásokat összevetik más véleményekkel.

Nos, az Internet, s ezen belül a különféle Usenet és egyéb fórumok, valamint a speciális témák megvitatására szervezôdött csoportok minden technikai lehetôséget biztosítanak ezeknek a feltételeknek a teljesüléséhez, a kérdés csak az, hogy a társalgások mennyiben használják ki deliberatív módon a lehetőségeket. Ezt pedig úgy lehet mérni, ha megvizsgáljuk, hogy a résztvevốk

1. mennyiben érik be a saját véleményük kinyilvánításával és a saját információik átadásával, s milyen mértékben igénylik mások információit, illetve mennyire érdeklődnek mások véleménye iránt, amennyiben ugyanis csak kinyilatkoztatásokkal találkozunk, ez kizárja az értelmes véleményütköztetés lehetôségét;

2. mennyiben tesznek a résztvevốk erôfeszítést arra, hogy megértsék és magukévá tegyék mások véleményét, és mások közleményeire válaszoljanak;

3. milyen mértékig válnak homogén csoporttá;

4. s végül - az ad hominem jellegú, s ezért vitaképtelen és megalapozatlan hozzászólásokhoz viszonyítva - milyen arányban tesznek közzé tartalmas, gyakorlati kérdésekre vonatkozó, racionálisan vitatkozó üzeneteket: ezzel lehet lemérni a társalgás kritikai-racionális jellegét. 
Mindezek alapján Wilhelm tartalomelemzést végez, melynek keretében kódolja az üzeneteket. Minden üzenet valamilyen megjelölést kap. Ez lehet például „informálás” (információ vagy vélemény közlése), „keresés” (információkérés valamilyen formában, akár nyíltvégű megjegyzés formájában), „témaindítás” (a társalgást elindító üzenet), „beépítés” (a társalgásban részt nem vevôktốl származó nézetek belefoglalása a hozzászólásba), stb.

A feltett kérdést illetően az eredmények nem túlságosan pozitívak. Davis elemzéséhez hasonlóan (Davis, 1999) Wilhelm is úgy találta, hogy az üzenetek túlnyomó része egyoldalú kinyilatkoztatás, a résztvevớk ritkán reagálnak egymás mondandójára, és a vélemények magas szintű homogenitást mutatnak, ami azzal fenyeget, hogy a más véleményen levők nem sokáig tartanak ki a velük szemben egységes mezónyben, már csak azért sem - mint kiderül az elemzésból -, mert túlságosan gyakoriak az agresszív hozzászólások. Az internetes társalgások tehát nemigen sokasítják a deliberatív fórumok számát.

Dahlberg (Dahlberg, 2001a) nyomán mégis azt mondhatjuk, hogy a „mennyire deliberatívak az online társalgások?” formában feltett kérdésünkre kapott alapvetően negatív válasz nem az út vége, ugyanis érdemes lehet bizonyos típusokat elkülöníteni a társalgások között. Dahlberg liberális individualista, kommunitárius és deliberatív típusokat különböztet meg. A nem vitatkozó, hanem pusztán önkifejezésre hajlandó társalgók elvileg az individualista típushoz sorolhatók, míg azok a fórumok, amelyek erôteljesen építenek offline aktivitásokra is, a kommunitárius típust képviselik, s végül az érdemi vitát folytatókat nevezhetjük deliberatívaknak.

Dahlberg tipológiája annak a belátásán alapszik, hogy a normatív politikatudományi megközelítés kritériumai szerint távolról sem minden internetes társalgás értékes, ám miért ne engednénk meg az internetezóknek is ugyanazt, amit az offline világ polgárai megtehetnek, vagyis azt, hogy ne csak deliberatív módon politizáljanak.

\section{Részvétel a politikai életben}

A részvétel internetes megjelenésének eddigi vizsgálatai két csoportra oszthatók. Az egyikbe tartozó kutatások a valós részvételt próbálták mérni, vagyis azt, hogy az állampolgárok és csoportjaik milyen módon használják politikai akciókra a világháló nyújtotta lehetôségeket. A másik csoport a részvételt elsősorban lehetôségként fogta fel, vagyis azt mérte, hogy mely országban, illetve egy-egy országon belül egyes társadalmi csoportokban milyenek a részvételt lehetôvé tevố Internet-hozzáférés mutatói. ${ }^{17}$

Az előbbi kérdésfeltevés egyik tipikus példája Jakob Linaa Jensen kutatása (Jensen, 2003). Jensen tanulmányát azért is érdemes megemlítenünk, mert itt nemzetközi, pontosabban lokalitás-közi összehasonlítást is találunk. Jensen az elsősorban Lincoln Dahlberg (Dahlberg, 2001b) vizsgálatai alapján elhíresült Minnesota Edemocracy résztvevôit veti össze néhány dán példával.

A megközelítés messzemenően politikai-szociológiai ${ }^{18}$ : a szerző először megvizsgálja a résztvevők Bourdieu-i értelemben vett tôkeellátottságát, vagyis gazdasági, szociális és kulturális hátterét, s ezután következik a minta elemzése abból a szempontból, hogy milyen részvételi adatok jellemzók rájuk. 
A gazdasági háttér felmérése jövedelemkategóriák alapján történik, s a mintát Jensen a minnesotai népesség, illetve az amerikai lakosság jövedelemadataival veti össze. Az eredmény az, hogy az Interneten politikailag aktív polgárok jövedelmi háttere szignifikánsan jobb, mint a másik két populációé. A dán adatok sem mondanak mást: a kulturális és a szociális tốkére irányuló felmérés is magasabb szintet mutat az aktív részvételt tanúsító polgárok körében, mint másutt.

A részvételi formák esetében a kutatás mindenek előtt arra keresi a választ, hogy az internetezô polgár mennyire tekinti saját magát a politika iránt érdeklôdônek általában is, nemcsak az internetes aktivitás terén. A továbbiakban Jensen a részvétel két fajtáját különíti el: a formálisat (ilyen például a választásokon való részvétel vagy a politikai szervezeti tagság) és az informálisat (ide tartozik például a barátokkal való politikai társalgás vagy a városházi politikai rendezvények látogatása).

A szakirodalom ugyan arra hívja fel a figyelmet, hogy az utóbbi időben csökkent a formális részvétel intenzitása, és nôtt az informálisé, a minnesotai minta mégis egyenletes aktivitást mutat mindkét fajta részvétel tekintetében, míg a dán minta esetében a formális részvétel jóval aktívabb. Ezek az eredmények arra engednek következtetni, hogy ugyanazok a személyek aktívak online, akik offline is azok, vagyis szociológiai értelemben nem igazolódott be az a várakozás, hogy azok, akik offline passzívabbak, a háttérbe szorultak, bátortalanok és gyengébb kommunikációs készségekkel bírnak, viszonylag intenzívebben igénybe fogják venni az új médiumot. A pártok után tehát immár az állampolgárok körében is azt találjuk, hogy a politikai élet a maga „normális” medrében folydogál tovább az Internet korszakában is.

\section{A kihívás-irodalom}

A tanulmány további részében azt vizsgáljuk, hogy az Internet megjelenése mely politikatudományi diskurzusokat tett újra fontossá, arra késztetve óket, hogy újraalkossák magukat. Az alábbiakban tehát olyan diskurzusokat mutatunk be, amelyeknek a fontossá válása mögött kitapinthatóan ott található az Internet megjelenése, ám ugyanakkor közvetlenül nem errôl szólnak, hanem a politikatudomány hagyományos kérdéseiról. Látnunk kell, hogy jobbára olyan témákról van szó, amelyek az utóbbi idóben nemcsak az Internet megjelenése miatt váltak érdekessé. Az adott terület gondjait ugyanakkor a szakmai vagy az értelmiségi diskurzusok nem utolsósorban az Internet igénybe vételével remélik megoldhatni.

Hangsúlyozottan újraalkotásról és nem paradigmaváltásról van szó. A régi paradigmák átmenetileg megkérdőjeleződhettek, de végül is egyelốre nem történik más, mint hogy bizonyos összetevőik értelme átalakul, a vizsgálatokat irányító kategóriák súlyaránya egymáshoz képest megváltozik, s esetleg új fogalmak tủnnek immár megkerülhetetleneknek. Az alábbiakban röviden, felsorolásszerúen olyan fogalmak megje-

\footnotetext{
${ }^{17}$ A részvétel kérdését Pippa Norris megközelítése egyszerűsíti le a hozzáférésre. Ez a leegyszerűsítő gesztus az egyik oka annak, hogy Norris munkájával a kihívás-irodalomról szóló részben foglakozunk.

${ }^{18}$ Hasonló megközelítéssel találkozunk Wilhelm (2000) tanulmányának erre vonatkozó fejezetében is.
} 
lenésérôl és átértékelődésérôl szólunk, mint a politikai közösség, a részvétel, a kommunikáció, a tömegkommunikáció, a szabadság és maga a politika. Ezeket két csoportra bontva, a politika alapfogalmaival és a politikai kommunikáció fogalmaival foglalkozunk.

\section{A politika alapfogalmai}

\section{A politika mibenléte}

A posztmodern világérzés, a marketing és a $P R$ divatja, a televízió zavarba ejtô ereje, majd az Internetben rejlő lehetőségek láttán a szakma és a szélesebb közvélemény is megküzdött azzal a kérdéssel, hogy a politikában vajon az intézmények, vagy a kommunikáció, a diskurzus szerepe tekinthetô-e elsôdlegesnek. ${ }^{19}$ Némelyek olyasfajta paradigmaváltást hajlamosak felsejleni látni, mint amilyen a második világháború után a behaviorizmus és az institucionalizmus között ment végbe a szakmában (Musgrove-Hug, 2003). Mint ahogyan a negyvenes években a politika és ezen belül a politikai kommunikáció legfontosabb vizsgálatai során természetes volt az emberek viselkedésében végbemenô változásokra koncentrálni, úgy lett utóbb - tulajdonképpen mindmáig - természetessé az, hogy a kutatók a politikát, illetve a politikai kommunikációt elsősorban intézmények (pártok, kormányzati szervek, tömegkommunikációs eszközök, politikai mozgalmak stb.) tevékenységének tekintsék.

Már a hatvanas, majd a hetvenes évektôl kezdve mind komolyabb kihívást jelentett a politikatudomány számára az, amit röviden a filozófia és a társadalomtudományok nyelvi fordulatának, posztmodern korszakának szoktak nevezni. A részletek taglalása helyett legyen elegendố itt annyit jeleznünk, hogy a nyelv és a kommunikáció helyértéke olyannyira megnôtt az utóbbi évtizedekben, hogy sokak számára immár az intézmények is csupán nyelvi konstrukciók, egy intézmény csak akkor létezik, ha kommunikál a környezetével, vagy ha legalább a (politikai) kommunikáció tárgyát képezi.

$\mathrm{Az}$ Internet megjelenése természetesen újabb lökést adott az olyan töprengéseknek, amelyek számára az új, posztmodern korszak egyik, vagy talán legfontosabb vonása a kommunikáció felértékelődése. A régi nagy, intézményekké szilárdult narratívák elhalása után a kicsi és éppen ezért csak folyamatosságuk révén létező narratívák kerülnek a középpontba. Az intézmények kétszeresen is hierarchikusak, egyrészt azért, mert belsố hierarchiával rendelkeznek, másrészt pedig azért, mert beilleszkednek az intézmények hierarchiájába. Ha azonban valamely intézmény érvényességét és létjogosultságát is a körülötte folyó társalgások határozzák meg,

\footnotetext{
${ }^{19}$ Az irányzat Magyarországon is megjelent a kilencvenes évek közepén, túlnyomórészt Szabó Márton munkáin keresztül.
} 
akkor a hierarchiák lebomlanak, és inkább rugalmas (kommunikációs) hálózatok után kell kutatnunk, ha meg akarjuk érteni a (politikai) világot.

Mára a kezdeti kommunikatív láz elmúlt, a diszkurzív és kommunikációs elemzések legitim módon betagozódtak a politikatudományba, de annyi kétségkívül megmaradt belőlük, hogy ma a politikát a maga kommunikációs aspektusai, a média nélkül nagyon nehéz tárgyalni a szakmában.

\section{A térrel és a testi jelenléttel kapcsolatos képzetek a politikában}

Ezzel a diszkurzív fordulattal magyarázható, hogy megszülettek olyan munkák, amelyeknek a szerzóit a politikában és a politikatudományban fontos szerepet játszó konstrukciós módok izgatják. Diana Saco (Saco, 2002) szerint politikai fogalmaink a térrel és a testi jelenléttel kapcsolatos, meghatározott képzetekhez kötődnek, és ugyanez elmondható arról is, ahogyan a politika számos kérdését megközelítjük.

A szabadságot például valamilyen szabad, nyílt térként képzeljük el, de egyben olyan térként is, amit külsố behatolás ellen különféle falak határolnak; azáltal nyílik számunkra szabad tér, hogy mások elốtt falak emelkednek a mi szabadságunkba való behatolásuk megakadályozása végett. Csakhogy a kibertér megjelenésével - nem véletlen, hogy néha az internetes kapcsolatrendszereket is térként közelítjük meg ezek a falak mindinkább átjárhatókká válnak, ami egyszerre félelmetes és felszabadító hatású. Például a cookie-k elfogadásával hozzájárulunk ahhoz, hogy mások egyre többet tudjanak meg rólunk, vagyis egyre közelebbról vizsgáljanak bennünket, és mások magánéletét illetốen így járunk el mi is. ${ }^{20}$ Egyszerre válunk láthatóbbakká és láthatatlanabbakká, hiszen miközben mások sok mindent megtudhatnak az érdeklődésünkről és ízlésünkrôl, ugyanakkor bárkinek vagy bárminek kiadhatjuk magunkat. Részt vehetünk továbbá mindenféle virtuális közösségben, de eközben folyvást félhetünk attól, hogy a többiek nem azok, aminek, illetve akinek mutatják magukat. Ezt a félelmet az okozza, hogy a bizalom megalapozója a testi jelenlét, a face-to-face kommunikáció - ha másért nem, akkor azért, mert bízunk abban, hogy képesek vagyunk a másik arcáról olvasni, illetve azért, mert a kommunikáció jelentôs része testbeszéd és nem puszta verbális teljesítmény. Ez politikailag azért is érdekes, mert az anonimitás, illetve annak állandó gyanúja, vagyis az, hogy a partner mégsem az, akinek véljük, lehetetlenné teszi például azt, hogy sejtsük, illetve biztosak legyünk abban, hogy a partner mögött milyen erók és érdekek állnak. Be kell érnünk azzal, hogy a szavait mérlegeljük, arra figyeljünk, amit mond, nem pedig arra, hogy ki mondja.

A térproblémához tartozik a mobilitás kérdése is. Azért tartozhat ide, mert az Internet egyik nagy adományának a közösségalkotás földrajzi, etnikai, szexuális és egyéb korlátaitól való szabadságot tekintik. Megint érzékelhetjük, hogy az identitást egyfajta térként fogjuk fel, s a különféle identitásterek között az Internet jóvoltából immár szabadon mozoghatunk. Másrészt felmerül a kérdés, hogy vajon szükségképpen el kell-e fogadnunk azt a hallgatólagos antropológiai előfeltevést, miszerint az „jó" dolog, ha az ember megszabadul földrajzi, etnikai, szexuális és egyéb kötöttségeitôl - és egyúttal az ilyen értelemben meghatározott közösségeitől is.

${ }^{20}$ Már McLuhan kijelenti, hogy a magánélet és annak szentsége kifejezetten az írásbeliség korszakához kötôdik, s annak leáldoztával, vagyis egy új uralkodó médium megjelenésével a magánélet felszámolódik. 
Ez a probléma azt a kételyt is felveti, hogy a földrajzi mobilitás szempontjából vajon tényleg unikális-e a mai társadalom. Charles Tilly azt mondja (Wellman, 2001:22), hogy az emberiség történelmében a mai kor csak azért látszik olyan mobilisnak, mert a megelőző kétszáz év kirívóan immobilis volt. Tilly szerint ebben az idôszakban a helyhez kötött vállalatok és az államok is az immobilitásban voltak érdekeltek, ezért tûnt természetesnek a térbeli kötöttség. Messzebbre visszanézve nyilvánvaló, hogy nem a mai társadalom az első mobil társadalom, vagyis a térhez kötöttség előfeltevése - történetileg nézve, de voltaképpen csak az Internet által lehetővé tett perspektívából - messzemenően problematikussá válik.

A másik végletet, a politikai intézményeket tekintve így a képviselet elvét is a térrel és a testi jelenléttel kapcsolatos képzeteinkre alapozzuk. Minél kisebb a tér, és ebbôl adódóan minél kisebb a közösség taglétszáma, annál autentikusabb a demokrácia, mert az emberek a saját testi jelenlétükkel vállalva a felelősséget, közvetlenül vehetnek részt a döntéshozatalban, és nem kényszerülnek képviseletre, annak mindenféle torzító következményével együtt. Nos, Saco szerint az Internet megjelenésével ezt is újra át kell gondolnunk, hiszen a világhálón keresztül közelebbi ismeretségbe kerülhetünk valakivel, aki a világ túloldalán él, mint azzal, akik a saját házunkban lakik.

Nem arról van szó, hogy a térrel és a testi jelenléttel kapcsolatos viszonyok megfordulnának, hanem arról, hogy akkor, amikor a politikáról gondolkodunk, talán értelmetlenné válik a hagyományos mértékben rábízni magunkat a térrel és a testi jelenléttel kapcsolatos képzeteinkre és metaforáinkra, hiszen az Internet világában egymással teljesen ellentétes társadalmi térkonstrukciók lépnek múködésbe.

\section{A politikai közösség mibenléte}

$\mathrm{Az}$ internetes társalgások vizsgálata során nemcsak azt a kérdést teszik fel a kutatók, hogy mennyire deliberatív a diszkusszió, hanem azt is, hogy a virtuális közösségek vajon közösségek-e egyáltalán, és ha igen, mennyire. Hasonlóképpen az Interneten szerveződő globális vagy lokális mozgalmak vizsgálatának is egyik fontos kérdése az, hogy ezek milyen értelemben tekinthetôk politikai közösségeknek. Jankowski (Jankowski, 2002) megállapítja, hogy a virtuális közösségekról értekezők pillanatokon belül terminológiai vitákba és fejtegetésekbe bonyolódnak. Magyarán: a közösségekkel kapcsolatos vizsgálódások még jóformán el sem indulhattak, mert az alapfogalom mibenlétét illetốn a tudományos közösség nem jutott közös nevezôre.

A közösség problémája ugyanakkor nagyon fontos egy másik irányból nézve is. Robert Putnam sokat tárgyalt könyve, a Bowling Alone (Putnam, 2000), nagyon élesen veti fel azt a kérdést, hogy milyen állapotban is vannak a közösségek ma az Egyesült Államokban, s látlelete szerint a helyzet rendkívül lehangoló. Putnam a válaszkeresés közben annak is utánanéz, hogy milyen a médiumok hatása a közösségek állapotára, és azt mondja, hogy a közösségek elsorvadásáért talán leginkább a televízió és a tömegkommunikáció felelős. Ugyanakkor azt is állítja, hogy az Internet esetleg visszafordíthatja ezt a kedvezőtlen tendenciát.

A közösség, illetve a politikai közösség problémája mindig is nehezen tisztázható kérdés volt. Michael Saward (Saward, 2003) szerint a közösségról valami olyasmit szokás gondolni, hogy az olyan, mint a család, esetleg mint valamilyen falu, 
csak nagyobb ezeknél. Ha pedig politikai közösségról beszélünk, akkor a nemzetállamra szoktunk gondolni, de úgy, hogy közben azért valamiképpen a közvetlen demokrácia nosztalgikus athéni modellje lebeg a szemünk elốtt.

Mi jellemzi tehát hagyományosan a politikai közösséget, vagy inkább a róla alkotott fogalmainkat? - A politikai közösség egyrészt tartós szerkezetekből áll, másrészt meghatározott népre alapozódik, továbbá adott összefüggó területre terjed ki. Mármost, a mai politikaelméleti próbálkozások támadják ezt a három attribútumot jelentôs részben az Internet alapján. Igen sok közösségről, nem utolsósorban az internetes közösségekről elmondhatjuk, hogy sem nem tartósak, sem nem ugyanahhoz a néphez vagy népcsoporthoz tartozó emberek alkotják ôket, és nem kötöttek területileg sem. Ugyanakkor mégsem állíthatjuk, hogy ne lenne köztük több politikai jellegú közösség is - például azok, amelyek időnként összegyúlnek valamely nagyvárosban, hogy tiltakozzanak a globalizáció ellen. Ezek - és maguk az akcióik is - az Interneten szerveződnek, a legkülönfélébb országok polgáraiból állnak, és nem alkotnak tartós szerkezeteket.

Van persze, aki inkább hálózatokról vagy kollektivitásokról beszél. Charles D. Raab és Christine Bellamy (Raab - Bellamy, 2001) számára ez lehetôvé teszi, hogy az egységes politikai közösség helyett a vegyes politikai intézményrendszer (mixed polity) fogalmát ajánlják. Ennek az a lényege, hogy a demokratikus társadalmat érdemesnek látszik abból a szempontból tagolni, hogy egységei milyen módon demokratikusak. A szerzôpáros megállapítja, hogy az Internet megjelenése nem változtatott a parlamentáris döntéshozatali mechanizmus demokratizmusán (a közvetlen részvétel nem váltotta fel a képviseleti rendszert), s a reinforcement tézis alapján ez nem is várható. Úgy látják azonban, hogy ez hosszabb távon sem kérdôjelezi meg az Internet politikai hasznosságát, csak éppen nem a nagy képviseleti rendszerekben, hanem más politikai egységekben játszik szerepet már most és a jövôben is. A politikai rendszer és a demokrácia tehát nem lehet minden szintjén és minden egységében homogén.

Ha azonban a politikai közösséget nem alapozza meg valamilyen hagyományos, hallgatólagosan elfogadott tényezô, s ha esetleg búcsút kell intenünk magának a közösség fogalmának is, akkor mi foghatja össze az embereket? - Az állam nem, hiszen ezek szerint az is csupán egy lesz a számos politikai egység közül, amelyekhez a polgárok tartozhatnak. Ez a keresgélés vezetett el sokakat a bizalom kérdéséhez (lásd például Uslaner, 2001; Schaal, 2003).

\section{Részvétel}

A politikai apátia a nyugati demokráciák régi problémája, hasonlóan a különféle demokratikus deficitekhez. Az Internet révén ezek enyhíthetők. Nem értünk-e félre azonban valamit ebben a kérdésben is?

Van Deth (Van Deth, 2001) rendkívül érdekesen közelíti meg a problémát. Elôször is konstatálja, hogy szinte ijesztô az a sebesség, amivel a szakirodalom által a politikai részvétel körébe sorolt tevékenységek köre bővül. Azt mondja, hogy míg a negyvenes években a politikai részvétel gyakorlatilag csak a szavazásokon való megjelenésből állt, ma már összesen körülbelül hetvenféle részvételi tevékenységet gyưjthetünk össze az erre vonatkozó irodalomból. A politikai részvételként számon tartott 
tevékenységeknek azonban nemcsak a változatossága nőtt meg, hanem a tere is, olyannyira, hogy manapság mindenkinek, aki a részvételrốl értekezik, gyakorlatilag a politika egészérôl kell szólnia.

Van Deth azt is kifejti, hogy ennek a bővülésnek mi lehet az oka. Az elsőrendű tényezô az állam tevékenységi körének folyamatos szélesedése, éppen a negyvenes évektől kezdve. Minél nagyobb az állam, annál fontosabbá válik, hogy az állampolgárok nyomást gyakorolhassanak rá, és annál többféle célból, különféle módokon kell az államra nyomást gyakorolni, a nyomás gyakorlását pedig eminens állampolgári politikai részvételként regisztráljuk. Ahogyan az állam hatóköre - akár a híres public-private partnership révén, vagyis a közélet és a magán szféra együttmúködési formáin keresztül - kibővül, úgy válik mind több, korábban magánjellegúnek tekintett tevékenység is politikailag relevánssá.

$\mathrm{Az}$ Internet megjelenése felgyorsította ezt a bővülési folyamatot, hiszen a korábbiak mellett megjelentek új részvételi lehetőségek, valamint olyan új tevékenységformák (internetes politikai társalgási fórumok, internetes akciók, a helyi önkormányzattal való kapcsolattartás új formái stb.), amelyeket a szakma politikai részvételként vehet lajstromba. ${ }^{21}$

\section{Demokrácia és deliberáció}

$\mathrm{Az}$ internetes társalgások vizsgálata a deliberáció és demokrácia viszonyával kapcsolatban különösen nagy hátszelet kapott a kilencvenes évek elején újra meglóduló vita nyomán. Habermas-nak a nyilvánosság megváltozásáról írott könyve ekkortájt jelenik meg angolul, majd az évtized közepén a téma újabb lökést kap Gutman és Thompson (Gutman - Thompson, 1996) könyvétôl, hogy végül az évtized végén John Dryzek (Dryzek, 2000 és 2003:1) okkal jelenthesse ki: a demokráciaelméletek közül ma a deliberatív felfogás a legerősebb.

Ezzel kapcsolatban az alábbi vitatémák merülnek fel:

A szavazás és a társalgás szembeállítása: egyre többen érvelnek amellett, hogy a demokrácia nem merülhet ki a szavazatszámlálásban, hanem csak tartalmi viták adhatják meg a legitimitását.

Minek kell deliberatívnak lennie? A meglevố intézményeknek? Esetleg új intézményeket, illetve intézményközi fórumokat kellene létrehozni a deliberáció lehetôvé tétele, majd további gazdagítása érdekében?

A meglevố fórumok közül melyek deliberatívak? Melyek nem azok, pedig annak kellene lenniük? (A parlamentnek például deliberatívnak kellene lennie, de nem az, mert ott jobbára párhuzamos monológok hangzanak el.)

Hogyan kellene a körülményeket úgy alakítani, hogy a különféle fórumok minél deliberatívabbak legyenek?

Legyenek-e mesterségesen létrehozott deliberatív fórumok, olyanok, amilyenekrôl Fishkin beszél, vagy reménykedjünk abban, hogy a spontán fórumok köztük az internetes fórumok is - releváns fórumokká fejlődnek?

${ }^{21}$ A témához lásd még Johansson (2003). 
Hogyan kellene a különféle nem formális és nem reprezentatív deliberatív fórumok eredményeit, politikai konszenzust elért állásfoglalásait ismertté tenni és érvényesíteni a kormányzat múködésében?

Pusztán azáltal tehát, hogy élénk politikai fórumok jöttek létre az Interneten, a demokráciát, illetve tágabb értelemben a politikát illetôen is felmerült egy sor paradigmáig hatoló kérdés.

\section{A politikai kommunikáció fogalmai}

\section{A new media terjedelme}

Richard Davis és Diana Owen (Davis - Owen, 1998) az Internetet az úgynevezett new media, az új médiumok egyikeként tárgyalja. Messzemenô párhuzamot vonnak a számítógép-hálózatok és az olyan médiumok között, mint például a „betelefonálós” rádió- és televízió-músorok vagy a televízióban látható tréfás politikai magazinok.

Azt állítják, hogy az Internet beleilleszkedik egy olyan koráramlatba, amelynek lényege a közönség bevonása a tömegkommunikációba, s ezen belül a politikai kommunikációba is. Az említett médiumok, illetve músorok mind erôteljesen feltételezik a közönség aktivitását, más szóval interaktívak. A közönség bevonása a betelefonálós músorok esetében kézenfekvő, de még ott is érvényesül, ahol szakértôk helyett a stúdióba meghívott hétköznapi emberek vitatnak meg közérdeklődésre számot tartó kérdéseket. Ez utóbbi músortípusban ráadásul népes stúdióközönség is jelzi a kommunikáció kétirányúvá válását, hiszen néha a közönség is hozzászólhat a vitához, de legalábbis tetszésnyiḷánítással mindig kifejezi a véleményét. Kérdéses persze, hogy ez a bevonódás, az interaktivitás mennyiben illúzió és mennyiben valóság.

Az Internetet azonban nemcsak az interaktivitás közössége helyezi egy csoportba ezekkel a műsorokkal, hanem bizonyos tartalmi vonatkozások is. Az új médiumok tartalmára általában is jellemzổ valamiféle mélységes bizalmatlanság, sôt esetenként utálat a bevett társadalmi-politikai intézményekkel és a politikusokkal szemben, de ami igazán elválasztja az új médiumokat a régiektôl, az a politikusokat érintő támadó kijelentések és az ad hominem jellegú támadások sokasága, mind egyes személyek, mind pedig bizonyos csoportok ellen. Ilyenekkel éppen olyan gyakran találkozhatunk a tréfás közéleti tévémúsorokban, mint az internetes fórumokon.

Richard Davis meggyőzôdése szerint tehát az Internet használatát egyáltalán nem a számítógép-hálózatok technikai adottságai határozzák meg, hanem a társadalmi és kulturális körülmények, illetve tendenciák. Ebból az következik, hogy az Internetet illetően például olyan vizsgálatokat érdemes végezni, amelyek éppen ezekre a tendenciákra kérdeznek rá. Az ott megjelenố tartalmak és a formák alapján az Internet vajon inkább a bulvárlapokhoz hasonló, illetve populárisabb médiumnak tekinthetô-e, mint az offline média? - Ez például úgy mérhető, ha összevetjük egy-egy újság offline és online változatát, a témák, a hangütés, a nyelvhasználat, az interaktivitás és más hasonló szempontok figyelembe vételével. 


\section{Kommunikáció-fogalom}

Végül érdemes néhány mondat erejéig megemlékeznünk arról a reakcióról, amellyel a kommunikációelmélet fogadta az Internet megjelenését.

Horányi Özséb (Horányi, 1997) azt mondja, hogy az Internet, de általában véve az új kommunikációs technikák megjelenése okán is újra át kell gondolni a kommunikáció fogalmát. A kommunikációelmélet hagyományosan beleértette a kommunikáció fogalmába azt, hogy a kommunikáció, a kommunikációs aktus végbemegy. Bármelyik kommunikációelméleti hagyományt vesszük is szemügyre, mindegyik hallgatólagosan előfeltételezi, hogy a kommunikációban többen vesznek részt, s hogy ebben az értelemben csak akkor érdemes kommunikációról beszélni, ha valamilyen tartalom átadása valóban megtörténik.

Mit kezdjünk azonban egy olyan helyzettel, amikor a mind több ember számára elérhető rádiós és televíziós csatornák megszázszorozódása, de főként a világhálón közzétett honlapok milliós nagyságrendû̉ megjelenése nyomán egyáltalán nem vehetố biztosra, hogy egy adott músorszám, illetve webtartalom bárkihez is eljut. A bizonytalanság fordított irányban is fennáll: éppen a közönség meglétének és kilétének a kiismerhetetlensége miatt még az is bizonytalan, hogy az elektronikus médiumok tartalomszolgáltatói - amikor kialakítják és elérhetôvé teszik a maguk üzenetét az adott médiumban - vajon gondolnak-e egyáltalán valamely meghatározott fogyasztóra vagy kommunikációs partnerra. Ezért megfontolandó Horányi Özséb javaslata, hogy a kommunikáció eddigi definíciói helyett vezessünk be egy újat, amely szerint a kommunikáció nem más, mint az elérhetôvé tett tartalom - függetlenül attól, hogy ez a tartalom valaha is eljut-e a címzetthez, illetve hogy van-e bármilyen, akár csak homályosan is meghatározott címzettje.

Ezt a kommunikáció-felfogást a közvetlenül és gyakorlatilag azonnal elérhető csatornák és honlapok óriási mértékủ felszaporodásán túl vonzóvá teszi a tartalomrögzítés eszközeinek tömeges elterjedése is. A magnetofonok és a videó készülékek elterjedése után a szintén bízvást tartalomrögzítőnek tekinthető számítógépek, majd a különféle fájlcserélố rendszerek és a hálózatok tömeges elterjedése logikusan vezet el újabb és újabb kérdésekhez. Felismertük, hogy kérdéses lehet kizárni a kommunikáció kategóriájából azt a temérdek felvett, letöltött, de esetleg soha meg nem nézett, meg nem hallgatott anyagot, amit sokszor maguk a felhasználók is csak azért rögzítenek, mert ezt olcsón és könnyen megtehetik, és mert ezeket az anyagokat bármikor elérhetővé akarják tenni a maguk számára. Magyarán: a kommunikáció egy része valószínúleg a felhasználók számára sem más, mint elérhetôvé tett tartalom. 


\section{Egy úi paradigma kísérlete}

Azért is foglalkoztunk a kommunikáció-fogalom ilyesfajta átalakulásával, mert a következőkben egy olyan paradigma kísérletét szeretnénk bemutatni, amelyik hasonló logikát, a valóság helyett a lehetőségek számbavételét helyezi a középpontba. Ilyen próbálkozásnak tekinthetjük Pippa Norris erőfeszítéseit. Norris ez idố szerint legfontosabb munkája ebben a témakörben - a tanulmány mondandójának fó irányát szembeállítandó az ördögi kör-elképzelésekkel - magyarul az „Angyali kör” címet kapta (Norris, 2001).22

Az ördögi kör természetesen a média és a politika viszonyának leírására szolgáló logika metaforája. A politikáról szóló információk legfontosabb forrása a modern társadalomban a tömegkommunikáció. Ez a tömegkommunikáció azonban résztvevôboól egyre inkább puszta fogyasztóvá fokozza le a jobb sorsra érdemes állampolgárt. Maga a politika, de az állampolgárok attitűdje is követi a tömegkommunikáció, a média logikáját; a politika egyre inkább szórakoztató, bulvárjellegú tevékenységgé válik, és a polgárok is egyre kevésbé várnak tôle ennél többet. A tömegkommunikáció pedig kiszolgálja és felerósíti ezt az ördögi kört - ezt a betegséget nevezik „médiakórnak” ${ }^{23}$.

Norris azonban éppenséggel angyali körrôl beszél. Azt mondja, hogy a médiakórdiagnózis terjesztôi a demokráciát illetôen túlságosan nagy súlyt helyeznek a politikai részvételre. Ó ezzel szemben Schumpeterhez nyúl vissza, aki megkülönbözteti a pluralista verseny, a politikai részvétel vagy participáció, valamint a civil és politikai szabadságjogok dimenzióit.

Eszerint a demokrácia értékének fokmérôi között csak az egyik a részvétel. Márpedig amennyiben például a pluralista verseny szempontjából vizsgáljuk a politikai kommunikációs tendenciákat, akkor azt látjuk, hogy az utóbbi évtizedekben a csatornák, és ezzel együtt a médiumokból nyerhetố tartalmak is óriási mértékben megsokasodtak - természetesen nem utolsó sorban az Internet megjelenése következtében. A hírforrások versenye intenzívebb lett, korábban sosem látott tartalmakhoz juthat hozzá az, akinek erre szüksége van. Ez pedig potenciálisan lefaraghat az eddig hátrányos helyzetben levők lemaradásából, legyenek azok akár pártok, politikai mozgalmak, politikusok vagy egyszerủ állampolgárok.

$\mathrm{Az}$ új médiumok - ide értve az Internetet is - megkönnyíthetik a civil társadalom mobilizálását, növelhetik a kormányzati szervek és általában a politikai élet átláthatóságát, a hatalmi intézmények elszámoltathatóságát, lehetôvé tehetik az állampolgári részvételt a döntéshozatali folyamatokban, a kormányzati szolgáltatások nyújtása és igénybe vétele egyaránt olajozottabbá válhat általuk, összességében tehát javíthatnak a képviseleti demokrácián. Ha a szakirodalom a fejlett demokráciákra jellemzô részvételi adatokat látva fanyalog is, azt azért nem vonhatja kétségbe, hogy az Internet óriási lehetőségeket nyit meg például az új demokráciák vagy a még tekintélyuralom alatt sínylődő országok civil társadalma és politikai mozgalmai előtt. ${ }^{24}$ Ezekben a társadalmakban még a hagyományos szabadságjogok kivívása és megszilárdítása a feladat.

\footnotetext{
${ }^{22}$ Az eredeti cím „Virtuous Circle”, ennek magyar változata a Médiakutató megnevezetlen fordítójának ügyességét dicséri.

${ }^{23}$ Szintén az elôző jegyzetben említett fordító leleménye.
} 
Talán ebbôl a rövid összefoglalóból is érződik, hogy Norris folyvást a lehetôségekrôl beszél, arról, hogy egyenes adásban nézhetjük a parlamenti üléseket, számtalan újságot olvashatunk, elektronikus leveleket küldhetünk, véleményt nyilváníthatunk stb... Az már sokkal kevésbé érdekli, hogy ezek a lehetôségek vajon valósággá is válnak-e, használják-e az emberek ezeket az eszközöket, és a nyilvánossághoz való hozzáférést illetően valóban kiegyenlítődnek-e az egyes pártok esélyei. Azért érezzük mégis egy új paradigma lehetôségét a Norris-i megközelítésben, mert kellóen elnéző és optimista szemléletet képvisel ahhoz, hogy bárkinek tessék, aki egyfelől hajlamos elfogadni a reinforcement tézist, másfelől pedig magáévá tudja tenni az Internet fontos jövőbeli szerepével kapcsolatban szőtt reményeket.

Pippa Norris-szal tulajdonképpen vissza is jutottunk a kiindulópontunkhoz, hiszen tanulmányunkat azzal kezdtük, hogy az Internetben szunnyadó lehetôségeket felsorakoztató szakirodalomban megtalálható gondolatmeneteket fogjuk ismertetni. Norris természetesen annyiban már túl van ezeken, hogy nagyon karakteres megközelítés alapján folytatott kiterjedt kutatásokat, s ezek nyomán állítja azt, amit állít. A következő időszak feladata ezután már nem az értelmiségi jövendölésekkel, hanem például a Norris felfogásával való szembenézés lesz.

\section{IRODALOM}

Althaus, Scott L. - Tewksbury, David (2000): „Patterns of Internet and Traditional News

Media Use in a Networked Community", Political Communication, 17:21-45.

Bentivegna, Sara (1999): La politica in rete. Meltemi, Roma.

Bentivegna, Sara (2002): Politica e nuove tecnologie della comunicazione. Laterza, Roma.

Berta Kata (2001): „A magyar parlamenti pártok internetes megjelenése”. Szakdolgozat, ELTE ÁJK, Politológus szak, Budapest.

Boda Zsolt (2003): „Election Campaign and Internet: An Analysis of the Web Sites of the Hungarian Political Parties". Paper prepared for the workshop 'The Changing Media and Civil Society', ECPR Joint Sessions of Workshops, Edinburgh.

Bryan, C., R. Tsagarousianou - D. Tambini (1998): „Electronic democracy and the civic networking movement in context", In: Tsagarousianou, R., D. Tambini és C. Bryan (eds.), pp. 1-17.

Community Informatics. Shaping Computer-Mediated Social Relations. (2001): Eds. Leigh Keeble and Brian D. Loader, Routledge, London.

Dahlberg, Lincoln (2001a): „Democracy via cyberspace. Mapping the rhetorics of three prominent camps" New Media and Society, 2.

${ }^{24}$ Hogy az új demokráciák paradigmatikus fontosságra tettek szert Pippa Norris számára, azt jelzi, hogy például a „Digital Divide?” c. munkájának 103. oldalán kétszer is rájuk hivatkozik, miközben esetenként gúnyos szavakkal marasztalja el a politikai életben való részvételt mindenek fölé helyezô szakírókat lásd például ugyanott a 104. oldalon. 
Dahlberg, Lincoln (2001b): „Extending the Public Sphere through Cyberspace: The Case of Minnesota E-Democracy".

http://firstmonday.org/issues/issue6_3/dahlberg/index.html

Danziger, J. Dutton - W. Kling, R. - Kraemer, K. (1982): Computers and Politics: High Technology in American Local Governments. Columbia University Press. New York.

Davis, Richard - Owen, Diana (1998): New Media and American Politics. Oxford University Press, New York.

Davis, Richard (1999): The Web of Politics. Oxford University Press, New York, Oxford.

Dányi Endre (2002): „A faliújság visszaszól. Politikai kommunikáció és kampány az Interneten" Médiakutató, 2002. Nyár.

De Rosa, Rosanna (2000): Fare politica in Internet. Come le nuove technologie influenzano la politica. Apogeo, Milano.

De Rosa, Rosanna (é.n.): "Surveying the cyberspace: considerazioni metodologiche" kézirat.

Democratic Governance and New Technology. Technologically mediated innovations in political practice in

Western Europe. (2000): Eds. Jens Hoff, Ivan Horrocks and Pieter Tops, Routledge, London.

Dryzek, John S. (2000): Deliberative Democracy and Beyond. Liberals, Critics, Contestations. Oxford University Press, Oxford.

Dryzek, John S. - Christian List (2003): "Social Choice Theory and Deliberative Democracy:

A Reconciliation". British Journal of Political Science, 33.

Gibson, Rachel - Stephen Ward (2000): "A Proposed Methodology for Studying the Function and Effectiveness of Party and Candidate Web Sites". Social Science Computer Review, Vol. 18 No. 3, Fall

Groper, Richard (1996): „Political Participation and the Internet: A Review Essay”. Political Communication, 13.

Gutman, Amy - Dennis F. Thompson (1996): Democracy and Disagreement. Harvard University Press, Cambridge.

Hill, Kevin A. - Hughes, John E. (1998): Cyberpolitics. Citizen Activism in the Age of the Internet. Rowman \& Littlefield, Lanham-Oxford.

Holmes, David ed. (1997): Virtual Politics. Identity and Community in Cyberspace. Sage, London.

Horányi Özséb (1997): „Az információs társadalom koncepciójától az információ kultúrája felé". Európai Szemmel, 1.

Jankowski, Nicholas W. (2002): „Creating Community with Media: History, Theories and Scientific Investigations". In: Handbook of New Media: Social Shaping and Consequences of ICTS. Leah A. Lievrouw and Sonia Livingstone (eds.) Sage, London

Jensen, Jakob Linaa (2003): „The Internet as a social and political field - the consequences of capital” Paper for the workshop „The Changing Media and Civil Society", ECPR

Johansson, Ylva (2003): “Civic Engagement in Change - The Role of Internet". Paper prepared for the workshop of ECPR, Edinburgh.

Jordan, Tim (1999): Cyberpower. The culture and politics of cyberspace and the Internet .Routledge, London.

Kumin Ferenc (2001): "Az on-line Baja” Médiakutató, 5. szám

Ladner, Sam: Dot-Com Stories: Online Journalists Talk about their work http://www.sfu.ca/ sladner.htm 
Margolis, Michael - David Resnick (1999): „Third Voice: Vox Populi Vox Dei?” http://firstmonday.org/issues/issue4_10/margolis

Mester Béla (2001): „Politikai közösség és a médiumok. A felhasználó mint állampolgár” In: Nyíri Kristóf (szerk.) A 21. sæázadi kommunikáció új útjai MTA Filozófiai Kutatóintézete, Budapest.

Morris, Dick (1999): Vote-com. How big-money lobbyists and the media are losing their influence, and the Internet is giving power back to the people. Renaissance Books, Los Angeles.

Musgrove, Ursula Häfliger - Simon Hug (2003): "Institutional Approaches in Political Science. Some Straight Talk" Paper prepared for presentation at the 2003 epsNet Plenary Conference, Paris

Musso, Juliet - Christopher Weare (2000): "Designing web technologies for local governance reform: good management or good democracy?" Political Communication, JanMar, Vol. 17, Issue 1

Norris, Pippa (2000): A Virtuous Circle. Political Communications in Postindustrial Societies Cambridge University Press, Cambridge.

Norris, Pippa (2001a): "Angyali kör? A politikai kommunikáció hatása a poszt-indusztrilis demokráciákra”. Médiakutató, 4. szám

Norris, Pippa (2001b): Digital Divide? Civic Engagement, Information Poverty and the Internet Worldwide. Cambridge University Press, New York

Norris, Pippa (2003): „Preaching to the Converted? Pluralism, Participation and Party Websites". Party Politics Vol. 9, No.1.

Pintér Róbert (2003): “Az Internet politikatudományi kutatásának intézményesülése” Politikatudományi Szemle, 2. szám

Putnam, Robert (2000): Bowling Alone. Simon and Schuster, New York

Raab, Charles D. - Christine Bellamy (2001): „Electronic Democracy and the 'Mixed Polity': Symbiosis or Conflict?" Paper prepared for the Grenoble Joint Sessions of European Consortium of Political Research, Manuscript.

Rash, Wayne (1997): Politics on the Nets. Wiring the Political Process. Freeman, New York.

Rheingold, Howard (1993): The Virtual Community. www.rheingold.com/vc/book

Riley, Thomas B. (2000): Electronic Governance and Electronic Democracy Living and Working in the Wired World The Commonwealth Secretariat, London

Saco, Diana (2002): Cybering Democracy. Public Space and the Internet. University of Minnesota Press, Minneapolis.

Saward, Michael (2003): „At the edge of political theory: political community and deliberative democracy". Paper for the epsNet plenary conference, Paris.

Schaal, Gary S. (2003): "Social Capital and Trust. New theoretical approaches to an old theme". Paper presented at the EpsNet Conference, Paris.

Schneider, Steven Michael (1997): Expanding the Public Sphere through Computer-Mediated Communication: Political Discussion about Abortion in a Usenet Nerosgroup. Ph.D. disszertáció, Massachusetts Institute of Technology. Cambridge, MA.

Schwartz, Ed (1996): NetActivism. How Citizens Use the Internet. O'Reilly****

Selnow, Gary (1998): Electronic Whistle-Stops. The Impact of the Internet on American Politics. Praeger, Westport.

Semetko, Holli A. - Natalya Krasnoboka (2003): "The Political Role of the Internet in Societies in Transition". Party Politics, Vol. 9, No. 1. 
Szabó Márton (1996): "Vázlat a politika diszkurzív értelmezésérôl”. Politikatudományi Szemle, 4. szám

Taubman, Geoffry (1998): „A Not-So World Wide Web: The Internet, Chine, and the Challenges of Nondemocratic Rule". Political Communication 15.

Tsagarousianou, R., D. Tambini - C. Bryan, eds. (1998): Cyberdemocracy. Technology, Cities and Civic Networks. Routledge, London and New York.

Uslaner, Eric M. (2000): „Trust, Civic Engagement, and the Internet”. Paper prepared for the Joint Sessions of the European Consortium for Political Research, Grenoble

Van Deth, Jan W. (2001): „Studying Political Participation: Towards a Theory of Everything?” Paper prepared for the workshop of ECPR, Edinburgh

Varga Barbara (2001): „Cyberkonkurencia. A magyar nyelvú on-line hírlapok kapcsolathálózati jellemzői”. Jel-kép, 2001/1

Vincent, David (1993): Literacy and popular culture : England, 1750-1914. Cambridge University Press, Cambridge.

Wellman, Barry (2001): „Physical place and cyberspace. The rise of networked individualism” In: Community Informatics...

Wilhelm, Anthony (2000): Democracy in the Digital Age. Challenges to political life in cyberspace. Routledge, New York

Wolton, Dominique (1998): Penser la communication. Flammarion, Párizs 